\title{
Innovation, Evolution and History of Technology in Industry
}

\author{
Tillerias Héctor ${ }^{1}$ \\ ORCID:https://orcid.org/0000-0001- \\ 6305-2711 \\ htillerias@gmail.com \\ Universidad de las Fuerzas Armadas \\ Quito-Ecuador \\ Álvarez Gabriela ${ }^{3}$ \\ ORCID:https://orcid.org/0000-0002- \\ 0882-3875 \\ gabriela.alvarez.velasco@udla.edu.ec \\ Universidad de las Américas \\ Quito-Ecuador
}

\author{
Segura Juan ${ }^{2}$ \\ ORCID:https://orcid.org/0000-0002- \\ 0625-0719 \\ juanjoelsegura@yahoo.com \\ Universidad Tecnológica Indoamérica \\ Quito-Ecuador
}

Recibido (07/08/20), Aceptado (18/08/20)

\begin{abstract}
This paper presents a description of the history of the technology used in the industries, its evolution regarding the use of energy and the processes that have innovated it within the industries. It describes the technology that highlighted industrial revolutions from the first to the present, and presents estimates of future trends. The evolution presents changes regarding energy consumption and efficiencies in the use of technologies in the industry. The innovation presents the changes or techniques implemented to obtain greater benefit from the technology and respond in a better way to the market demand. Clear trends are identified in the increased use of technology in industries with respect to their labor and energy consumption.
\end{abstract}

Keywords: Technologies, industrial revolutions, innovation.

\section{Innovación, Evolución e Historia de la Tecnológica en la Industria}

Resumen: Este artículo presenta una descripción de la historia de la tecnología utilizada en las industrias, su evolución en el uso de la energía y los procesos que la han innovado dentro de las industrias. Describe la tecnología que destacó las revoluciones industriales desde la primera hasta el presente y presenta estimaciones de tendencias futuras. La evolución presenta cambios en cuanto al consumo de energía y eficiencias en el uso de tecnologías en la industria. La innovación presenta los cambios o técnicas implementadas para obtener un mayor beneficio de la tecnología y responder de mejor manera a la demanda del mercado. Se identifican tendencias claras en el mayor uso de tecnología en las industrias con respecto a su consumo de mano de obra y energía.

Palabras Clave: Tecnologías, revoluciones industriales, innovación. 


\section{I.INTRODUCTION}

The term revolution suggests a radical change in the use of technologies and approaches to perceive the world [1], whose consequences affect economic systems and social structures. Throughout history and around the world, three industrial revolutions have been known, which have triggered a fourth revolution and optimizes all the knowledge learned, creating spaces to take gigantic leaps in terms of information technologies (ICT).

As technology evolves, the enormous capacity and potential from which different industrial sectors can benefit becomes more visible, as has been demonstrated in other times, where the main favored were the industries of that time, who changed the production paradigms.

These revolutions occur with shorter intervals [2], producing methodological changes by companies, to make them more competitive and thus occupy all the available technological knowledge to achieve advantages over their competitors, thus generating impulses to new manufacturing eras.

Technologies are developing depending on the needs of the context and the environment, these advances create exponential leaps that in turn generate new stages of production, and for this they are drunk to keep the processes updated and provide greater knowledge to the productive tasks. Creating all this system or optimizing it, causes a higher quality and speed in the manufacture of products, which gives a perfected technological evolution.

The intensive use of different technological tools creates a new philosophy in the industry concerned with optimization and continuous improvement with massive digital media that use the global network to follow trends and thus be updated in terms of production processes [2].

Technological evolution in industries is making great strides, managing to create such a capacity for adaptation, employment and modification that accelerated response to changes in the environment is elementary, through the creation and development of new technologies [3].

Advanced countries owe their economic growth to technological innovation, which strengthens scientific capacities, thus generating innovative processes and products [1] - [4]. These improvement processes create greater technological competencies that favor the industry, granting advantages that must be kept constant, as new and improved instruments are being created every time, which requires permanent industrial updating.

The innovation aims to grant a new benefit to a product or service that is known, being this in any of the creation, production or sales processes, using a new technology at an industrial level, to grant an unpublished product that complies with the consumer and business demands [5].

New and technical improvements in the use of technological tools will grant greater sustainability over time to companies, with success only those that internalize innovation as their ability to meet the changing market demands without losing quality and price, ensuring the future thanks to the potential of technological innovations [5].

\section{II.DEVELOPING}

\section{A.History of Technology in Industry}

Technology has accompanied the paradigm shift in the history of the industrial revolution, its implications affect multiple areas of society and the world environment.

The first industrial revolution carried out in Great Britain in 1784, was characterized by the growth of the textile industry, in which the use of great inventions such as the steam engine, the telegraph, the railway, the sewing machine, stand out. the light bulb, among others [6]

In the second industrial revolution beginning in 1870, important scientific and technological advances were made. Telegraph and rail networks, gas and water supply and sewerage systems are created, which had previously been concentrated in some cities. In addition, the automobile is created and disseminated by the Ford company, the telephone, the airplane, the phonograph, the cinema, the extraction of oil, dynamite, among other products that changed the vision of the known world are also offered [7].

The third industrial revolution, carried out since 1969, is known as the intelligence revolution and has been characterized by the deployment of advances such as the use of renewable energies, globalization with the use of the internet, transportation of electric vehicles, hybrids, etc. [8].

Finally, the fourth industrial revolution, known as revolution 4.0, mixes cutting-edge production techniques with intelligent systems that integrate with organizations and people [9]. Nanotechnology, virtual reality and 
augmented reality, robots, 3D and 4D printing are then produced, which are currently prominent.

Along with the industrial revolution, the use of energy has been changing. Before the first industrial revolution, most energy sources came from wood, which was used to light fires in homes, workshops and in the existing manufacturing sector. Other natural sources were also chosen, such as moving water flows to power mills. In the United States, the industrial revolution gained importance at the beginning of the 19th century [10], coal was used in the first instance as fuel for steam engines. The second industrial revolution was characterized (in the mid and late nineteenth century) by the use of oil and gas as the most representative energy sources, which were used in inventions and applications with the use of the internal combustion engine. The automobile and airplanes were propelled by these fuels and later electricity appeared, which as a technical advantage had the capacity for storage and transport in a standardized way, greatly facilitating their consumption.

Fig. 1 shows the most outstanding technological aspects in industrial evolution, which have set a guideline for the social development of nations.

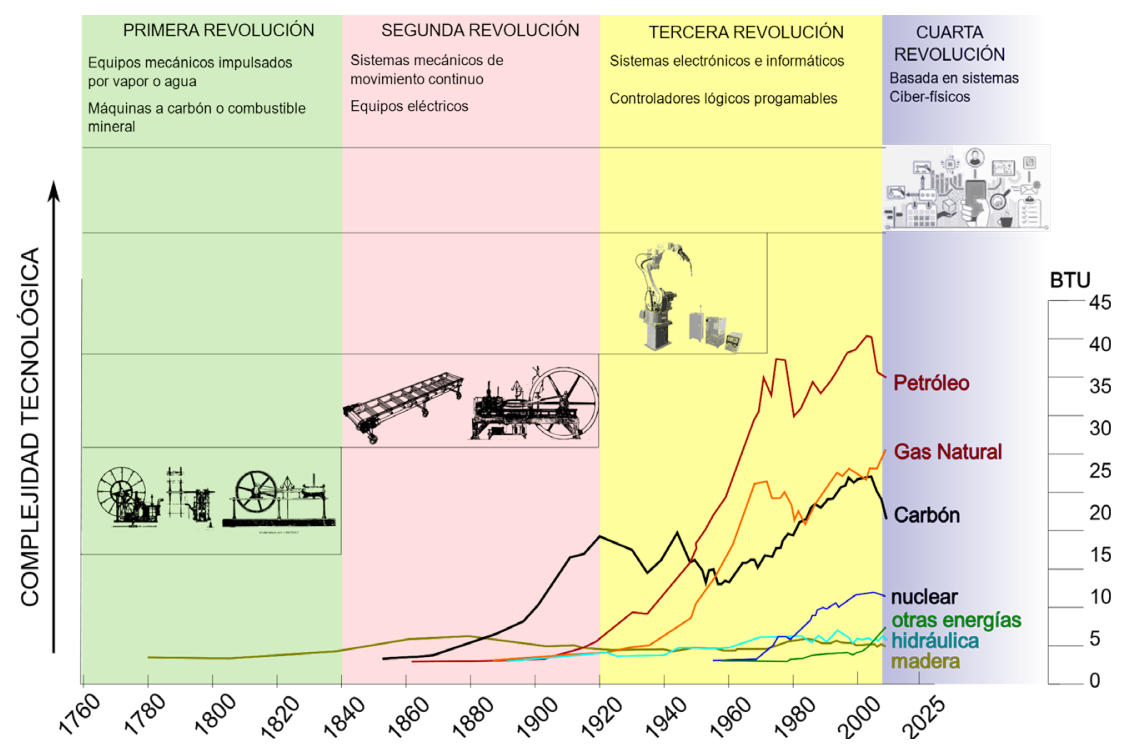

Fig. 1. Technological aspects of the Industry over time.

The technological complexities are an indicator parameter of change, the evolution according to the years and the past revolutions observed in fig. 1. The energy sources and their consumption stand out, and finally a description of the mechanical and / or electromechanical systems used in each stage [11] - [12].

The first industrial revolution, also known as industry 1.0, in the 18th century, was characterized by the use of energy obtained from water, either in steam or by its potential energy. The machines used in these industries generated mechanical work from the expansion of steam or the combustion of fossil minerals.

The second industrial revolution known as industry 2.0, in the nineteenth century, was characterized by the use of energy obtained from oil, either in mechanical systems or in continuous motion. The steam engine is no longer used but the turbine and the combustion engine. The machines used in these industries were of electrical (dc) and hydraulic origin.

The third Industrial Revolution (Industry 3.0), developed in the 20th century, was characterized by the use of energy obtained from hydrogen and renewable energy, whether in electronic and computer systems. In addition, the use of nuclear energy was relevant. The machines used in this period were primarily programmable logic programmers.

The fourth industrial revolution, known as Industry 4.0, occurs in the 21 st century and is characterized by the use of energy obtained from alternative sources. In addition, to use much of the energies of the third revolution. The machines used are cyber-physical systems.

Fig. 2 shows a comparison of the source over time, it is observed that for more than a century, the energy consumed that has predominated has been that from coal, its consumption increasing over the years until 1959 [13]. The diversity in the use of new energy sources has been remarked since 1950, the year in which the use 
of different types of energy, stored in different batteries for use without direct connection to a source becomes important, due between other reasons to the growing need for energy by world economies. Today fossil fuels predominate, accounting for $80-85 \%$ of total energy consumption since 1970 [14].

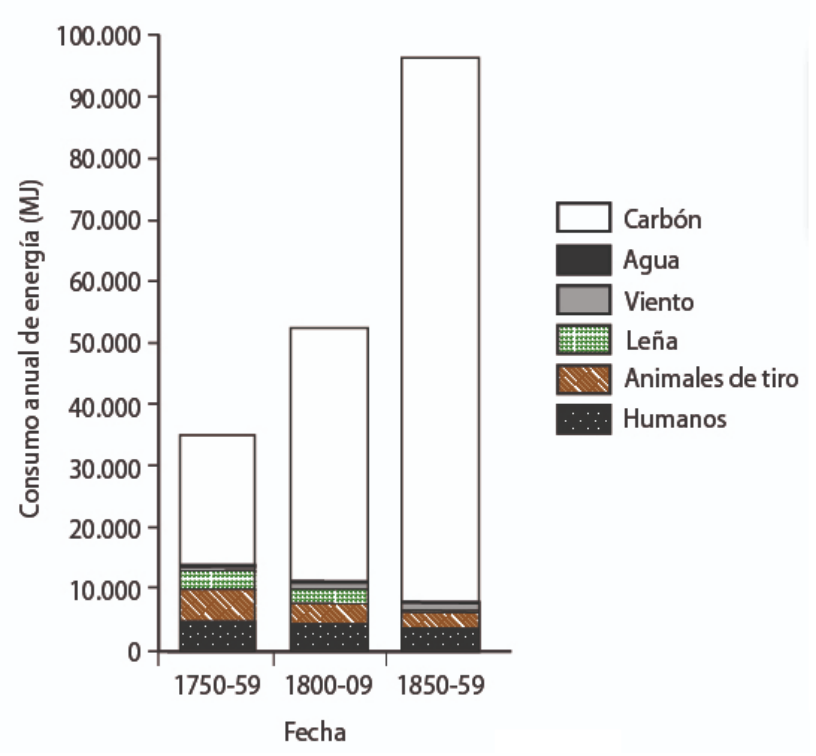

Fig. 2. Annual energy consumption according to its type.

\section{B.Industrial Innovation}

The process that generates value and continuous improvement in industries is consolidated through innovation in its technologies. Manufacturing applications have generated sustainable change in three fundamental areas: product, process and management.

This implementation of updated and repowering technologies with ICT achieves better production control through industrial innovation, positively influencing the final quality of both the process and the good or service created, in the same way reducing the associated values, thanks to the technological systems that store, process and deliver information relevant to production. This causes a scenario where conditions are changing profoundly. Technological dominance is becoming more and more essential, not only for growth and prosperity, but even for survival [15].

Industries are increasing and adopting more and more innovative technologies, orienting the emphasis on differentiation, production and commercialization. Adding biotechnology or ICT for this purpose, requiring both skilled labor and restructuring of the same organization. Thus, progress in innovation creates incredible development opportunities for countries that decide to adopt this initiative for their industries, however, in Latin America and the Caribbean this rise is more languid than in other territories (Fig. 3), evidenced in the results of the 2019 global innovation index, prepared each year by the World Intellectual Property Organization (WIPO).

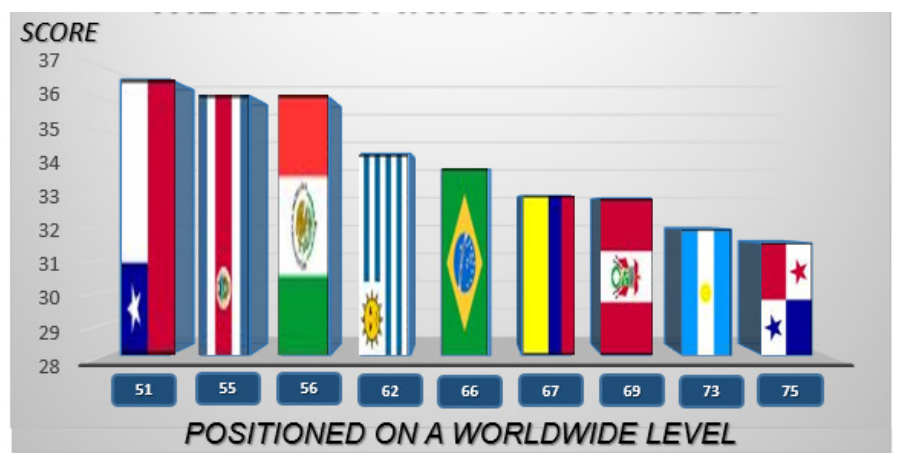

Fig. 3. Most innovative countries in Latin America [16]. 
Technology allows companies to look beyond the simple offer of products and services, taking an interest in creating deeper and more meaningful relationships with people [17], giving rise to both internal and external demands on companies and positioning the use of technology as an accepted means for the evolution and growth of both industry and people. The innovation of technology is related and allows the development of multiple areas of constant change for every industry (Fig. 4).

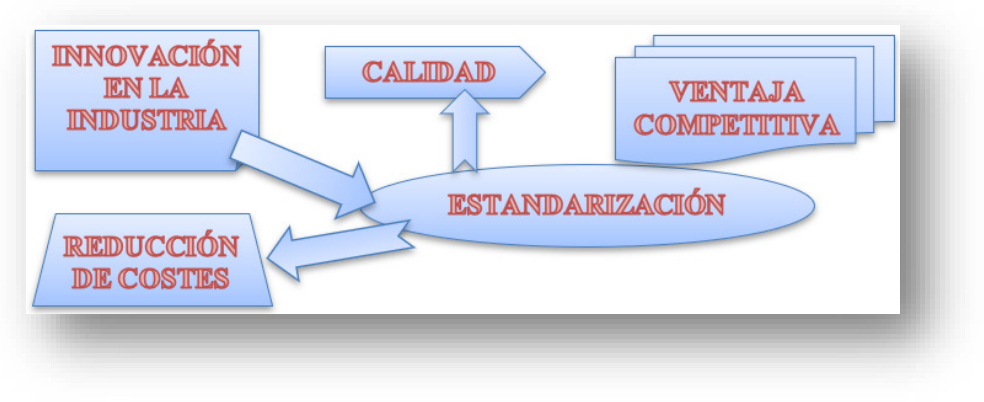

Fig. 4. Areas related to and benefited by industrial innovation.

The increasing inclusion of digital technologies is creating an environment that connects the demands of constant and demanding change of the users for an operational efficiency and superior services. Thus, technological innovation is the determining factor for a company to maintain or disappear from the market. Innovation generates the competitive advantages that allow companies to position themselves correctly [18].

Some authors assure that technological innovation is the main source for the development of societies, the promotion of culture and the promotion of the economy of nations [19]. These new development paradigms are the link that makes possible the new trends in education, in the profile of new professionals and in the promotion of new forms of industrial development.

\section{III.METHODOLOGY}

A bibliographic review was carried out taking into account the four industrial revolutions, for this, it considered the evaluation in 15 articles that address the most relevant aspects of changes in industrial technology. Statistics on energy consumption have been considered throughout history, as well as descriptions of the use of technologies in each industrial stage. Four books have been reviewed that address aspects to establish the parameters of verification of the types of technologies applied in each historical epoch in the industry, in order to build understandable graphic diagrams that will easily condense the information relevant to industrial technological change, and reflected the importance of innovation in the industry along with its types of classification according to authors. 


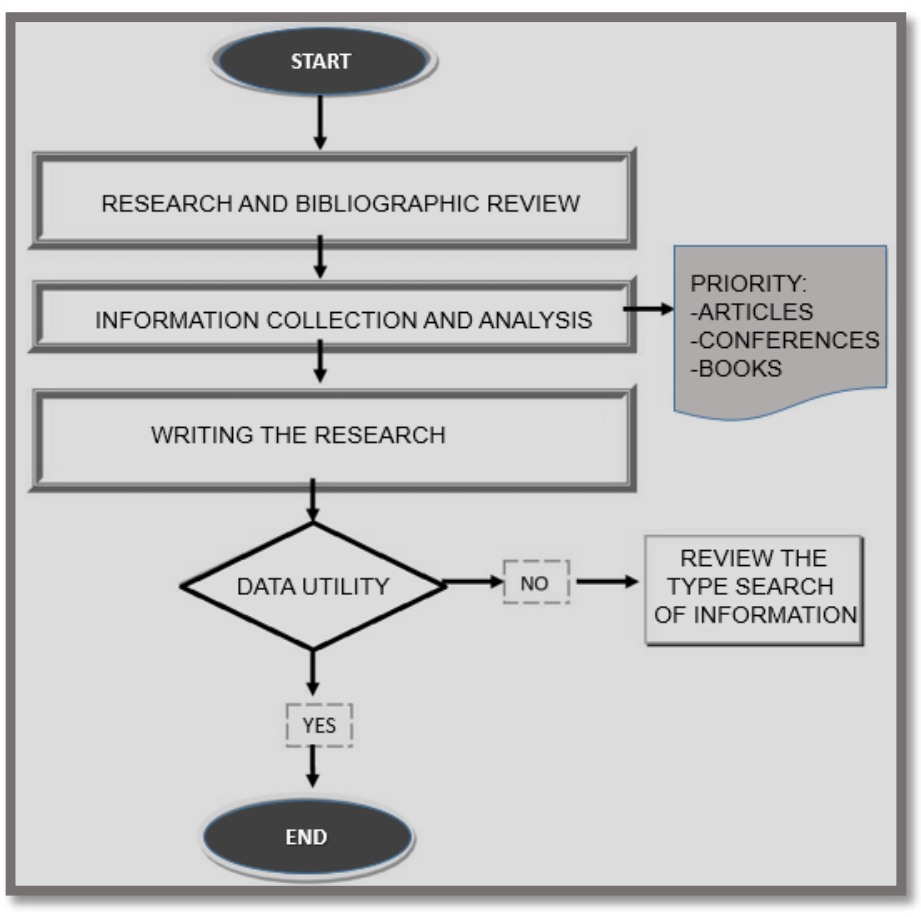

Fig. 5. Investigation model

\section{IV.RESULTS}

Once the bibliographic review was carried out, it was evidenced that the greatest technological leap occurred in the third industrial revolution, since in this period a large part of the technologies and energies used in industry 4.0 are discovered, where only part of the knowledge acquired, but which shows great potential with the arrival of artificial intelligence and automated robots, this creates a reduction in the times generated for the leaps from industrial revolution to revolution, as a result of the large amount of technology used.

It was also possible to corroborate that technology is a fundamental part of industrial development at all times, and that it is subject to human aspirations and trends to improve the quality of processes, as well as the impersonation of humans for optimization in the mass production of products.

Another aspect that stands out in industrial evolution is its impact on educational processes, which considerably influence the generation of new professional careers that will be included in the academic curricula of each generation affected by the industrial revolution of its time.

The results show that innovation is fundamental for technological development, and that this in turn is necessary for the creation of new forms of work, new products and markets that focus on social, cultural and human needs.

\section{V.CONCLUSIONS}

$\mathrm{T}$

Technology is undoubtedly one of the forces that allow the development of a country, since the industry faces the challenge of being competitive on a daily basis and is forced to change constantly. Thus, each research and development unit of the companies has the responsibility of optimizing their production models through technological innovation and continuous improvement in all manufacturing phases to become competitive.

Innovation is a key term within industrial processes since it generates new ideas and inventions in the activities for their development and use. Therefore, innovation represents the challenge of production companies, to be sustained over time and transcend with a view to more efficient processes that guarantee the quality of their products.

Ideas become innovations, which then represent new products, services or procedures, create a paradigm shift 
at a global level when they are massed, founding the so-called industrial revolutions that will guide the new societies of the new times.

\section{REFERENCES}

[1]G. M. GROSSMAN, «Innovation and Growth in the Global Economy,» Cambridge, 1991. [2]S. NAVA, «New Paradigm of Big Data in Industry 4.0 era,» TOG ( A Coruña), 2018.

[3]L. Kim, La dinámica del aprendizaje tecnológico en la industrialización, Suam Foundation, 2000

[4]H. Pack, E.Westphal, Industrial Strategy and Technological Change, Journal of Development Economies, vol. 4, pp. 205-237, 1986.

[5]A. ESCARDINO, «La innovación tecnológica en la industria cerámica de Castellón,» Boletin de sociedad Española Ceramica y vidrio, vol. 40, 2001.

[6]M ASHTON, T.S. «The lnduetrtal Revolutlon, 1760-1830. Oxford University Press, 1948». La Revolución Industrial. F.C.E., México, 1950.

[7]E. WRIGLEY, The Supply of Raw Materials in the Industrial Revolution, Economic History Review, 1962. [8]R. CANTOR, La tercera revolución industrial. Universitas Humanística, 2004, Recuperado a partir de https://revistas.javeriana.edu.co/index.php/univhumanistica/article/view/9908.

[9]K. SCHWAB, Cuarta Revolución Industrial. Madrid: Debate, 2016.

[10]C. MACHICADO, Las revoluciones industriales. INESAD: Desarrollo sobre la Mesa, 2018, disonible en: [http://inesad.edu.bo/dslm/2018/08/las-revoluciones-industriales/].

[11]R. Mendez, Las revoluciones industriales. Madrid: Instituto geográfico nacional, Gobierno de España, 2017.

[12]N. ROSENBERG, Technological Change in the Machine Tool Industry 1840-1910, Journal of Economic History, XXXIII, 1963.

[13]V. FTHENAKIS, J. E. MASON Y K. ZWEIBEL . «Energy Policy, the technical, geographical, and economic feasibility for olar energy to supply the energy needs of the u.s. » vol. 37, págs. 387-399; 2009.

[14]P. DEANE, The First Industrial Revolutlon. Cambridge University Press, London , 1965. La Primera Revolución Industrial. Penlnsula, Barcelona, 1968.

[15]C. PÉREZ, La empresa ante el cambio tecnológico. Conferencia ante el Congreso Internacional de Estrategias Gerenciales Asociación de Ejecutivos del Estado Carabobo, 1996.

[16]S. Chevalier, Los países más innovadores de América Latina, Statista Newsletter de infografías. Statista, 2019, Recuperado de https://es.statista.com/grafico/18823/paises-latinoamericanos-mejor-calificados-en-innovacion/

[17]O. NICOLAT, Innovación tecnológica en la industria de retail, Red Forbes México. Forbes, 2018, Recuperado de https://www.forbes.com.mx/innovacion-tecnologica-en-la-industria-de-retail/

[18]A. CAMACHO, Impacto de la gestión tecnológica en la competitividad de las pymes caleñas. Entramado, (vol. 4, núm. 1), pp. 8-16, 2018.

[19]R. BENÍTEZ, F. SUÁREZ, Fomento de la cultura emprendedora en jóvenes de la provincia de esmeraldas, Universidad Ciencia Y Tecnología, 2019, Recuperado a partir de https://uctunexpo.autanabooks.com/index. $\mathrm{php/uct/article/view/95}$ 


\section{CURRICULUM SUMMARY}

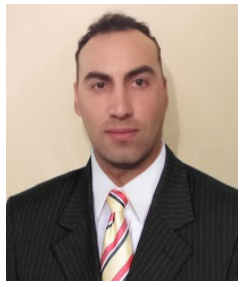

Héctor Tillerias, Master in Planning and Strategic Direction, graduate from the University of Armed Forces, Quito-Ecuador, degree in Military Sciences from the war Academy in Santiago-Chile, expert in supervision, management and training of human resources, with experiences in risk prevention and health promotion and quality of life in the workplace.

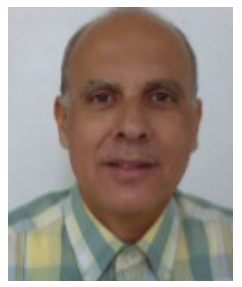

Juan Segura, professor de la Universidad Tecnológica Indoamérica, sede Quito. Desarrolla sus investigaciones en el área de Innovación tecnológica, ingeniería eléctrica y distribuciones de potencia.

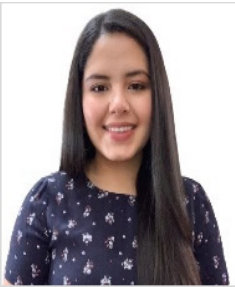

Gabriela Alvarez, Eighth semester Industrial Production Engineering student at the Universidad de las Américas in Quito - Ecuador. Considered an outstanding student, she is therefore a teaching assistant in various subjects of the career and its coordination. With participation in various conferences on national and international industry. 